\title{
気候変動のゆらぎと台風桨害に関する研究 \\ Study on the Multi-decadal Fluctuation of Climate Change and Typhoon
}

\begin{abstract}
三島豊秋 ${ }^{1}$ ・ 山下隆男 ${ }^{2} \cdot$ 松岡潔照 $^{3} \cdot$ 駒口友章 $^{4}$
Toyoaki MISHIMA, Takao YAMASHITA, Kiyoteru MATSUOKA and Tomoaki KOMAGUCHI

Climate indices such as El Niño-Southern Oscillation in the Pacific Ocean were investigated to find out a relationship between multi-decadal fluctuations of climate change and tropical storms, in particular typhoon in North West Pacific based on the historical record of typhoon-induced disasters. It was found that the ratio of the category.5 typhoon among the all historical typhoon and recorded developed-low pressure systems in the West Pacific was increased in La Niña dominant period. It is foreseeable that attentions on more intensified and frequent tropical storms, typhoon, should be drawn in the forthcoming La Niña dominant period from this study. The similar results were obtained from the historical record of hurricanes in the Atlantic and in the East Pacific Ocean.
\end{abstract}

\section{1. 緒言}

気候変動に関する政府間パネル（IPCC）第4次評価報 告書（AR4）に扔ける将来予測では, 地球温暖化に伴い 大型台風㧍よび豪雨などの異常気象による災害の増加が 眯念されることが述べられている.またこの報告書には, 各国の研究機関によって実施された最新の地球温暖化に よる気温の指数的な上昇トレンドの予測結果も示されて いる，関連する各分野では，それらの予測された地球温 暖化に伴う指数的な気候変動によって引き起こされる異 常気象による災害の増加に対応するために，100年先を 見据えた緩和策掞よび数十年先を見据えた適応策が模索 されている.

気候変動には, IPCCにおける地球温暖化の予測結果に 見られるような指数的に変化するトレンド以外に，準周 期的に変動するゆらぎが存在する.太平洋赤道上におけ るエルニーニョ・南方振動（ENSO：E1 Niño-Southern Oscillation）はその代表的なものである. それ以外にも， 太平洋上における太平洋十年規模振動（PDO：Pacific Decadal Oscillation), 大西洋上に扔ける大西洋数十年周 期振動（AMO：Atlantic Multi-decadal Oscillation）㧍よび 北大西洋振動（NAO：North Atlantic Oscillation), インド 洋におけるインド洋ダイポール現象（IOD：Indian Ocean Dipole）などがある。これらの気候変動のゆらぎによる 気象場の変化は, 沿岸各国の気象災害に影響を及ぼして いることが知られている.

我が国の気象場を影響下に置くENSOおよびPDOは太 平洋での代表的な気候変動のゆらぎである.山下ら

\begin{tabular}{|c|c|c|}
\hline 1 正会員 & 博 (工) & $\begin{array}{l}\text { (株) 碧浪技術研究所 技術部長 } \\
\text { 広島大学産学連携センター客員研究員 }\end{array}$ \\
\hline 2 正会員 & 博 (工) & 広島大学教授 大学院国際協力研究科 \\
\hline $\begin{array}{l}3 \\
4 \text { 正会員 }\end{array}$ & 博 (工) & $\begin{array}{l}\text { (株) 長谷上コーボレーション } \\
\text { (株) 碧浪技術研究所 代表取締役 }\end{array}$ \\
\hline
\end{tabular}

（2008）は，1950年〜 76年程度までの約 30 年間のラニー ニャ卓越期には, その後の 1976年〜現在までの約 30 年 間のエルニーニョ卓越期に比べ, 我が国では台風災害お よび寄り迴り波のような異常気象擾乱による災害が多発 していることを明らかにした。ささらに，その約 30 年の準 周期的な長期トレンドに着目すると, 今後の約 30 年間は ラニーニャ卓越期に入るために 1950 年〜 76年程度まで の期間と同様に気象災害が頻発する可能性があり, 特に 数十年先を見据えた地球温暖化に対する適応策を策定す る場合にはその気候変動のゆらぎによる影響を考慮する 必要があることを提案している.

我が国に来襲する台風以外にも，大西洋および東太平 洋におけるハリケーン, インド洋におけるサイクロンな どが知られている。これらのトロピカルサイクロンは, 我が国における台風と同様に, 各海洋における気候変動 のゆらぎの影響を受けていることが予想される。これら のトロピカルサイクロンと気候変動のゆらぎとの相互関 係を明らかにすることは, 気候変動のゆらぎを考慮した 地球温暖化に対する適応策の必要性を示す上で重要な課 題の一つであると考えられる.

本研究では, このような観点から, 気象災害を引起す 代表的な気象擾乱であるトロピカルサイクロンに着目 し, 気候変動のゆらぎと台風とのより詳細な相互関係の 検討と同時に, 各海洋での代表的な気候変動のゆらぎと そこでのトロピカルサイクロンとの相互関係について検 討する.

\section{2. 気候変動のゆらぎの指標}

気候変動のゆらぎの代表的なものとして, 太平洋上に おけるENSOおよびPDO, 大西洋上におけるAMOおよ びNAO, さらにインド洋上におけるIODなどがある.こ れらのゆらぎを表す指標は，それぞれ MEI（Multivariate 

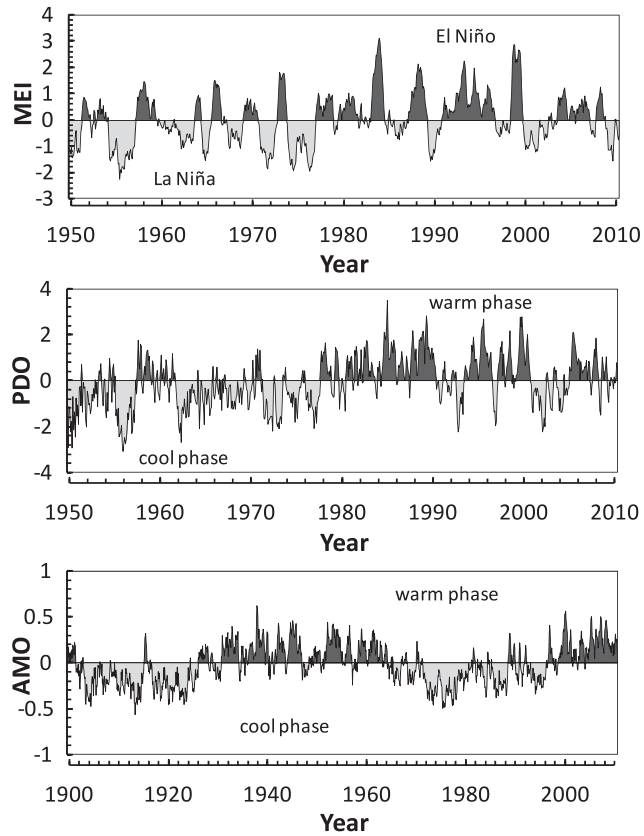

図-1 MEI，PDOおよびAMOの経年変化

ENSO Index)，PDO，AMO，NAO，およびDMI（Dipole Mode Index）と呼ばれている. 図-1に MEI，PDOおよび $\mathrm{AMO}$ の経年変化を示す．検討ではENSOから IOD までの 5 種類の気候変動のゆらぎと各海洋でのトロピカルサイ クロンとの関係について検討したが，一定の関係が見い だせたものは太平洋上に扔けるENSO およびPDO，大西 洋上におけるAMOであったことから，図-1にはこれら3 種類のゆらぎの指標のみを示す。

ENSO 指標である MEI は，この值が正值のときエルニ ーニョであることを，負值のときラニーニャであること を表す，PDOでは，この值が正值のときはwarm phaseと， 負值のときはcool phase と呼ばれる．ENSOおよびPDO共 に1976年辺りを境に，それより以前はラニーニャもしく はcool phaseの卓越期であり, またその後はエルニーニ ヨもしくはwarm phase卓越期であることが見て取れる. MEI は1950年以降の值が，またPDOは1948年以降の值 がNOAAのHPで公開されている (NOAA ESRL HP).

ENSO およびPDOが太平洋上での気候変動のゆらぎで あるのに対して，AMOは北大西洋上での海面水温の中期 の変動を表す指標である，PDOの場合と同様に，AMO が正值のときはwarm phase と，負值のときはcool phase と呼ばれる。図-1の最下段に示されているように，30〜 40 年程度の周期で変動しており，またENSOおよびPDO の卓越期の周期を 30 年程度とすると, $\mathrm{AMO}$ の変動周期 は $1 / 4$ 周期程度位相がずれているのも特徵的である．MEI およびPDO と同様に，1856年以降の AMOの值はNOAA のHPで公開されている.

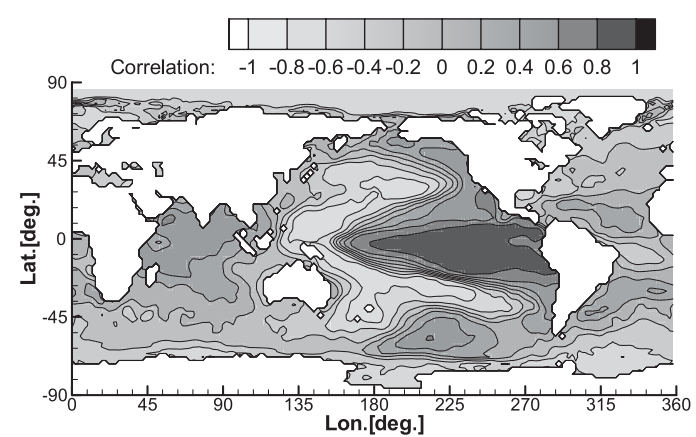

(a) MEI

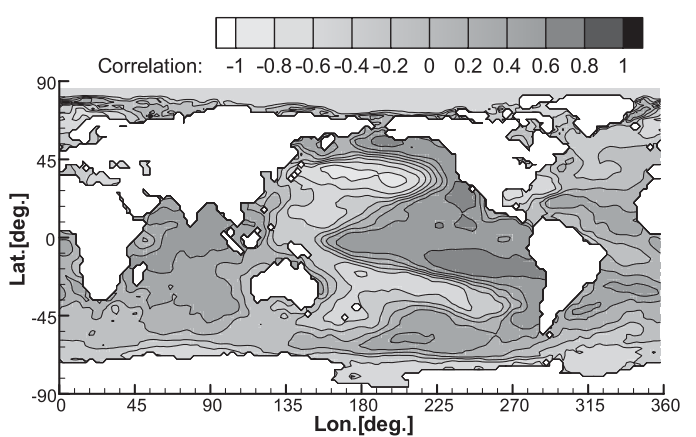

(b) PDO

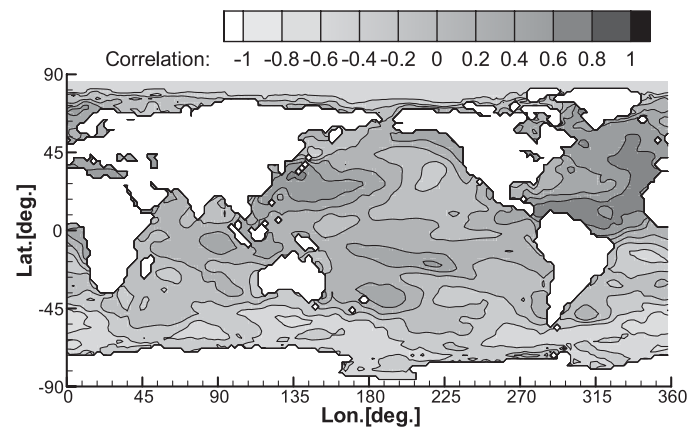

(c) $\mathrm{AMO}$

図-2 各ゆらぎの指標と海面水温との相関係数

\section{3. 気候変動のゆらぎによる海面水温の変動}

トロピカルサイクロンの発生域，発生数，強度，拈よ び経路などの特性は多くの気象要因の影響を受けている と推測されるが，最も影響を受けやすいものとして海面 水温が挙げられる. 図-2に，1950年〜2007年までの MEI, $\mathrm{PDO}$ 㧍よびAMOの各気候変動のゆらぎの指標の時系列 と各地点の海面水温の時系列変動との相関係数の分布を 示す。このとき, 海面水温デー夕にはICOADSを補正 · 補完することにより求めたERSSTデー夕を用いている (Smith・Reynolds，2004).なお，ここでの海面水温の変 動は各地点での月平均からの偏差であり, また全球平均 の変化のトレンドも除かれている.

図-2に示すMEIおよびPDO と海面水温の変動との相関 
係数の分布は両者とも類似した傾向を示すが，MEIでは 赤道付近で, PDOでは北太平洋上での相関がより強い傾 向にある，また，両指標共に日本近海では負の相関であ り，ENSOにおけるラニーニャもしくはPDOにおける cool phaseのときには日本近海のこの海域の水温が高くな る. 一方, AMOでは北大西洋の赤道付近に高い正の相 関をもつ海域があり，この海域ではAMOがwarm phase のときに海面水温が高くなる.

図-3は, 図-2に示す相関係数の分布に各点の海面水温 の変動の標準偏差を乗じたものである。この分布は温度 の次元を持ち, 各気候変動のゆらぎによって起こる海面 水温の変動の平均的な振幅を表すと考えられる.この図 に扔けるMEI抄よびPDOに着目すると，これらの指標に よって起こる日本近海から赤道付近までの海域における

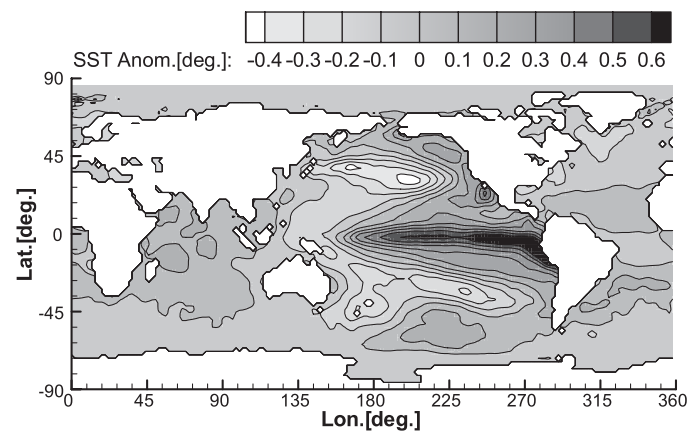

(a) MEI

SST Anom.[deg.]: $-0.4-0.3-0.2-0.1 \quad 0 \quad 0.10 .20 .30 .4$

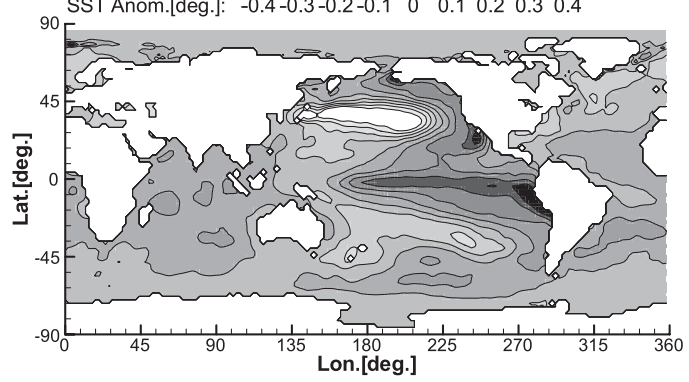

(b) PDO

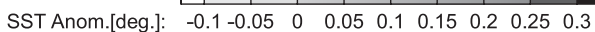

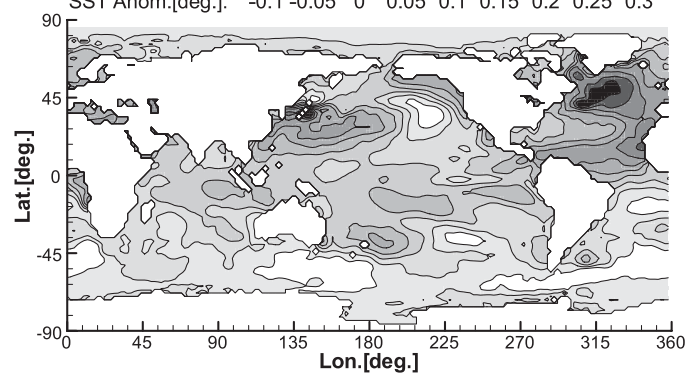

(c) $\mathrm{AMO}$

図-3 各ゆらぎによる海面水温の変動

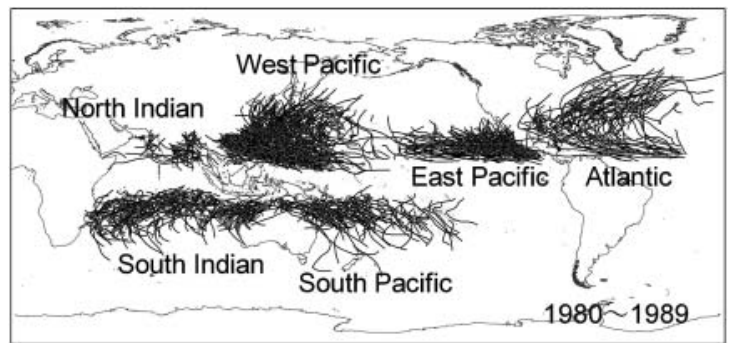

図-4＼cjkstart経路図の一例（1980年～89年）

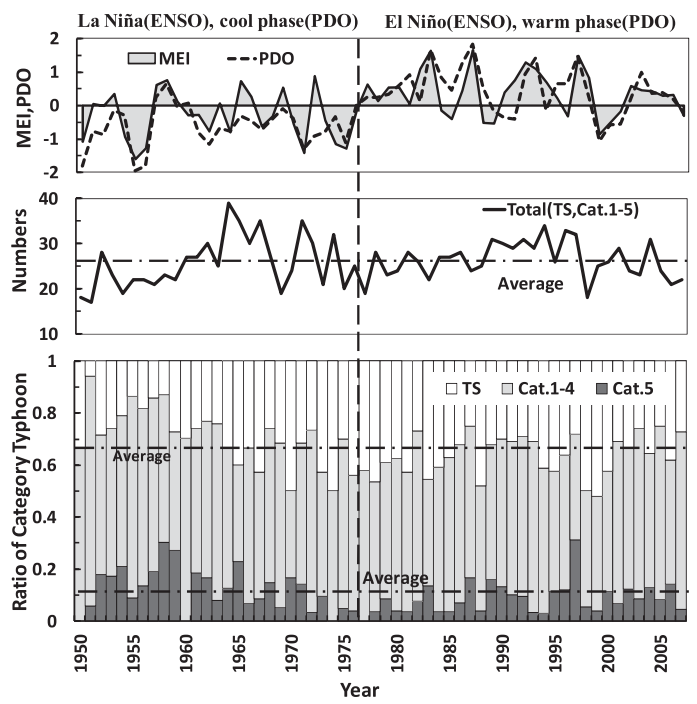

図-5 MEIおよびPDO と台風発生数の関係

海面水温の変動は, $\pm 0.1 \sim 0.2{ }^{\circ} \mathrm{C}$ 程度であることが分か る、また，これらの気候変動のゆらぎによって起こる東 太平洋の赤道付近の海域での海面水温の変動は, $\pm 0.8^{\circ} \mathrm{C}$ を超える. 一方, AMOによって起こる北大西洋における 海面水温の変動は, 赤道付近で $\pm 0.2^{\circ} \mathrm{C}$ 程度であることが 分かる. 日本近海から赤道付近までの海域は台風の発生 域に，東太平洋の赤道付近の海域は東太平洋における八 リケーンの発生域に, また北大西洋の赤道付近の海域は, 大西洋におけるハリケーンの発生域に対応している.

\section{4. 気候変動のゆらぎと台風特性}

各海洋でのトロピカルサイクロンデータには, Unisys Weather HPで公開されているべストトラックデータ，お よび気象庁RSMC Tokyo HPで公開されているそれを用い る (Unisys Weather HP ; 気象庁 RSMC Tokyo HP). 図-4 にUnisys Weather HPで公開されているベストトラックデ ータの経路図の一例を示す。このUnisys Weather HPには, 大西洋, 東太平洋, 西太平洋, 南太平洋, 南インド洋, および北インド洋の6海域でのトロピカルサイクロンの ベストトラックデータが公開されている. 実際には南太 平洋を除く5つの海洋に対して検討を行い, 西太平洋の 
台風，東太平洋抒よび大西洋のハリケーンの 3 種類のト ロピカルサイクロンとそれぞれの海域に対応する気候変 動のゆらぎに対して有意な結果が見られた。

図-5は, ENSO指標の MEIおよびPDO, 台風発生数お よびカテゴリー別の台風発生数の比率を示したものであ る。なお，図中での台風のカテゴリーはUnisys Weather での分類（Tropical Storm, Category1-5）に従っている. この図によると，1950年〜 76年のENSOにおけるラニー ニャもしくはPDOに抢ける cool phase卓越期には，年間 発生する台風に占めるカテゴリー1-5の比率は，1977〜 2007年のENSOにおけるエルニーニョもしくはPDOにお ける warm phase卓越期に比べ高くなっているのが分かる. また，それはカテゴリー5の大型台風の比率が高くなっ たためであることが分かる。すなわち，ラニーニャ卓越 期にはカテゴリー5の大型台風の発生比率が高くなる.

図-6に卓越期別のカテゴリー5の台風に対する経路密度 を示す。この図における台風経路密度は, 空間をメッシ ユ $2^{\circ} \times 2^{\circ}$ に分割したときに，各メッシュを通過する台風 個数の台風発生数に対する比率として定義されている。 こ の図に示されているカテゴリー5の台風経路密度は，ラニ 一ニャ卓越期にはエルニーニョ卓越期に比べ西側へ片寄 り，北側へ広がる傾向になっている。これは，台風の発 生域が日本に近くなると同時に，日本本土を縦断し易く なることを表している，図-7には，ENSOにおけるエルニ 一ニョ拉よびラニーニャ，もしくはPDOにおける cool phase およびwarm phaseの卓越期別に，日本へ上陸した台 風の最低気圧順の頻度が示されている。実際に，最低気

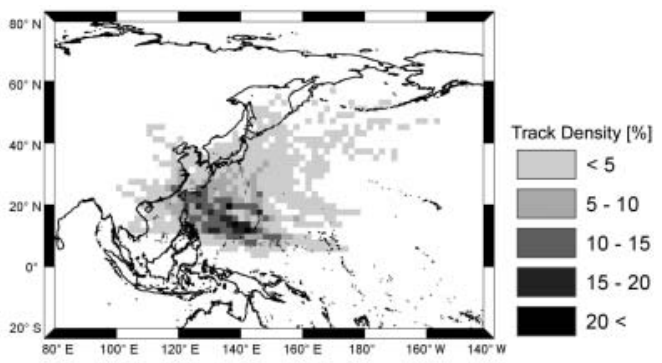

(a) ラニーニヤ卓越期（1951年～76年）

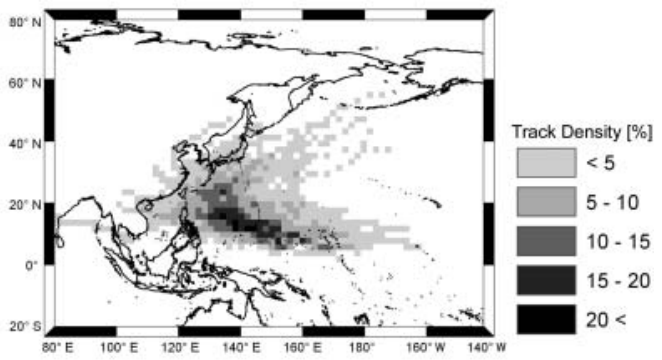

（b）エルニーニョ卓越期（1977年～2007年）

図-6 卓越期別のカテゴリー 5 台風の経路密度

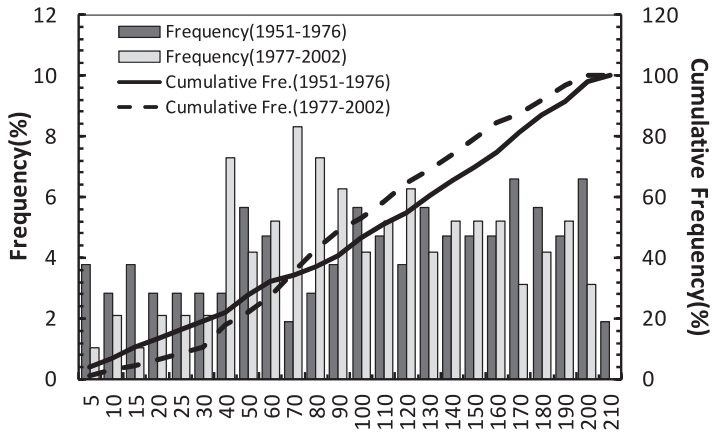

Ranking of Typhoon(Lower Pressure Order)

図-7 最低気圧順の上陸台風の頻度

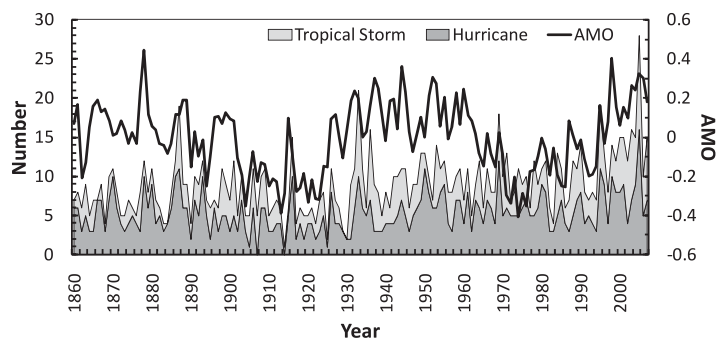

(a) AMO と大西洋のハリケーン

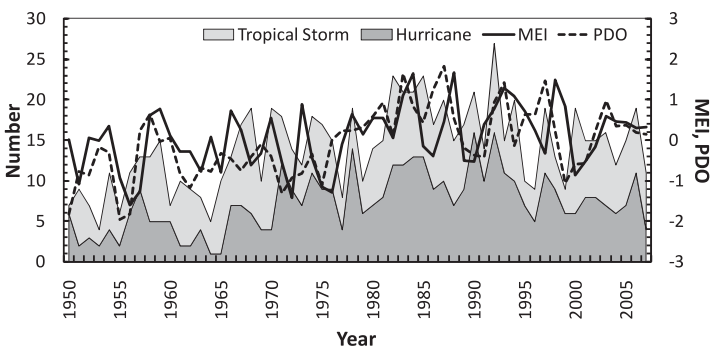

（b）MEIおよびPDO と東太平洋のハリケーン

図-8 気候変動のゆらぎとハリケーン発生数の関係

圧順の上位 30 位までの大型台風に関してはラニーニャ卓 越期の頻度は高く，この期間には大型台風が上陸しゃす いことが分かる.

\section{5. 気候変動のゆらぎとハリケーン特性}

図-8には，気候変動のゆらぎと大西洋および東太平洋 に打けるハリケーンの発生数が示されている。 それぞれ の海域に対応する気候変動のゆらぎとして，大西洋では AMOが，また東太平洋ではENSO指標の MEI およびPDO が示されている．図-8（a）に示された大西洋における $\mathrm{AMO}$ とハリケーンの発生数では, 若干ではあるが AMO の変動傾向とハリケーンの発生数の変動傾向に対応が見 られ，warm phaseのときにハリケーンの発生数が増加す る傾向にある．特に，1970年以降のハリケーンの発生数 の増加傾向は, その期間での $\mathrm{AMO}$ の増加傾向に対応し ている. 


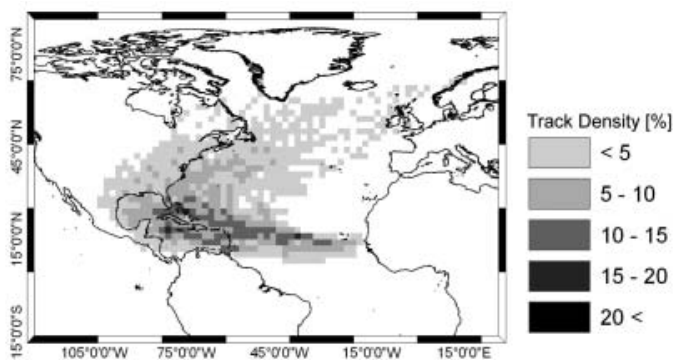

(a) warm phase (AMO)

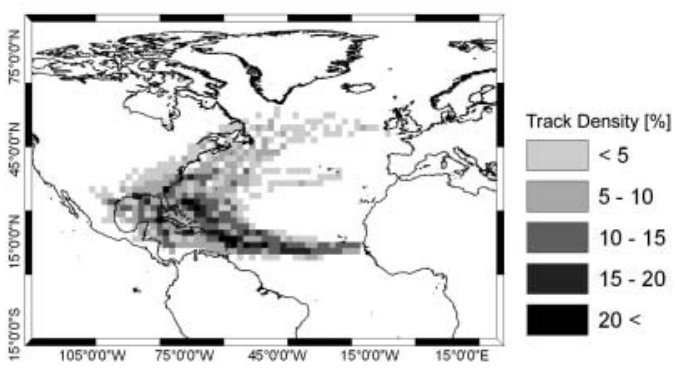

(b) cool phase (AMO)

図-9 大西洋でのカテゴリー4-5ハリケーンの経路密度

一方，図-8（b）に示された東太平洋におけるMEIおよ びPDOとハリケーンの発生数に対しては, MEIおよび $\mathrm{PDO}$ の変動に対応してハリケーンの発生数は増減する傾 向が見られ，ENSOにおけるエルニーニョ卓越期もしく はPDOにおける warm phase卓越期にはハリケーンの発生 数は増加する傾向にある。 また，大西洋の $\mathrm{AMO}$ とハリ ケーンの発生数との関倸に比べてもより明確な傾向が表 れている。これは，図-5に示したMEIおよびPDO と台風 の発生数との関係と比べても, 発生数に直接影響を及ほ している点でより明確な傾向であると言える。この結果 には，図-3で示したように，それぞれの海域での気候変 動のゆらぎによる海面水温の変動は東太平洋でのハリケ ーンの発生域が最も大きく, 次いで大西洋におけるそれ の発生域および西太平洋での台風発生域の順に小さくな ることが反映されていると推測される.

図-9には，AMOの2つのphase別に整理した大西洋で のカテゴリー4および5のハリケーンの経路密度が示さ れている. 同様に, 図-10には, エルニーニョ・ラニー ニャ別に整理した東太平洋でのカテゴリー4および5の ハリケーンの経路密度が示されている. 大西洋のハリケ ーンは, AMOの warm phaseのときにはcool phaseのとき に比べ全体的に広い範囲に経路密度が分布する傾向にあ り，上陸し易い傾向にあると推測される．同様に，東太 平洋のハリケーンにおいても, エルニーニョ時には経路 密度が広い範囲に分布する傾向にあり，日本近海まで到 達するハリケーン数が増加する傾向が見られる.

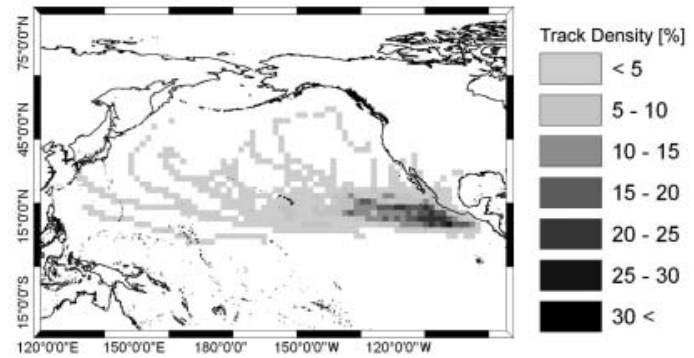

(a) エルニーニョ (ENSO)

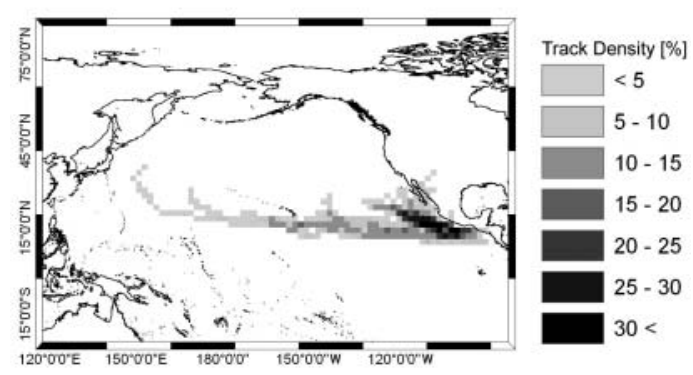

(b) ラニーニャ（ENSO）

図-10＼cjkstart東太平洋でのカテゴリー4-5ハリケーンの経路密度

\section{6. 結語}

各海洋における気候変動のゆらぎとトロピカルサイク ロン特性との関係について検討を行った。その結果，日 本へ来襲する台風は，ラニーニャ卓越期（PDOの cool phase）にはエルニーニョ卓越期（PDOの warm phase）に 比べ大型台風の発生比率が増加し，またそれらは上陸し 易くなることが明らかになった，さらに，大西洋での八 リケーンはAMOの warm phaseのときにcool phaseに比べ 発生数が増加し, また上陸し易くなることが, 東太平洋 でのそれはエルニーニョ期にはラニーニャ期に比べ発生 数が増加し，また広い範囲に広がる傾向にあることが明 らかになった。

各海洋における気候変動のゆらぎは 30 年〜 40 年程度 の周期で変動しており, 各海洋でのトロピカルサイクロ ン災害に影響を及ぼしていると推測される。地球温暖化 に対する適応策を策定には，それらのゆらぎによる気象 災害への影響を考虑する必要があると考えられる。

\section{参 考 文 献}

気象庁 RSMC Tokyo HP: http://www.jma.go.jp/ jma/jma-eng/jmacenter/rsmc-hp-pub-eg/RSMC_HP.htm.

山下隆男・駒口友章 · 三島豊秋（2008）：気候変動のゆらぎ を考慮した海岸保全の適応策への一考察, 海岸工学論文 集, 第55巻, pp. 1341-1345.

NOAA Earth System Research Laboratory (ESRL) HP: http://www.cdc.noaa.gov/data/climateindices/.

Smith, T.M. and R.W. Reynolds (2004): Improved extended reconstruction of SST (1854-1997), J. Climate, Vol.17,pp.2466-2477.

Unisys Weather HP: http://www.weather.unisys.com/hurricane/. 